\title{
APPLICATION OF DRY CELL HHO GAS GENERATOR WITH PULSE WIDTH MODULATION ON SINJAI SPARK IGNITION ENGINE PERFORMANCE
}

\author{
Bambang Sudarmanta $^{1}$, Sudjud Darsopuspito ${ }^{2}$, Djoko Sungkono ${ }^{3}$ \\ ${ }^{1,2,3}$ Fuels and Combustion Engineering Laboratory, Department of Mechanical Engineering, Sepuluh Nopember \\ Institut of Technology, Surabaya, Indonesia
}

\begin{abstract}
Dry cell HHO gas generator performance optimization was done by varying the duty cycle of pulse width modulation, pwm. HHO gas generated subsequently applied to the Sinjai spark ignition engine port injection, 2-cylinder $650 \mathrm{cc}$ with gas inlet mechanism using a venturi. Variations performed on HHO gas generator is the duty cycle of pwm, ie 20\%, 40\%, 60\%, $80 \%$ and $100 \%$ (or the same as non pwm). The parameters of performance were calculated includes specific energy input, efficiency and temperature of the HHO generator. HHO gas is obtained then used as a fuel mixture in the Sinjai engine and inserted through a venturi mechanism which is mounted on the duct of combustion air inlet. Furthermore, the effect of the addition of HHO gas on the performance of the Sinjai engine measured includes parameters of torque, power, BMEP, specific fuel consumption and thermal efficiency. Sinjai engine performance optimization done on setting ignition timing for minimum advance for best torque, MBT mechanism. The results show that optimum performance of HHO gas generator is generated by pwm system with $40 \%$ duty cycle with parameters such as specific energy input of 33,121 MJ/kg, generator efficiency of 20,064\% and generator temperature can be maintained below $60^{\circ} \mathrm{C}$. Application of $\mathrm{HHO}$ gas generator in point above on standart ignition timing Sinjai engine produce in an increase of performance such as torque, power, BMEP and thermal efficiency respectively of $2.27 \%, 2.76 \%$ and $3.05 \%$ and a decrease of bsfc $7.76 \%$. Retarded ignition timing is adjusted to MBT is able to increase performance such as torque, power, thermal efficiency, respectively 6.55\%, 7,65\%, 15,50\% and a decrease of bsfc 22,06\%.
\end{abstract}

Keywords: Sinjai Engine, HHO Gas Generator, HHO Gas, PWM, MBT And Engine Performance

\section{INTRODUCTION}

Hydrogen is one of the new and renewable energy which has a calorific value of $120 \mathrm{MJ} / \mathrm{kg}$. The energy value is much greater than with gasoline, diesel or CNG gas fuel resvectively [1]. One way to get hydrogen is by electrolysis of water, a method for separating hydrogen and oxygen in water using an electric current. The equipment used is called $\mathrm{HHO}$ gas generator, which consists of dry and wet type. Electrolysis process at the $\mathrm{HHO}$ gas generator will separate the atoms bond $2 \mathrm{H}_{2} \mathrm{O}$ into $2 \mathrm{H}_{2}$ and $\mathrm{O}_{2}$, which this gas is known as $\mathrm{HHO}$ gas or Brown's gas [2,3].

HHO gas can be used as a fuel extender for gasoline, diesel or CNG gas to then be used in internal and external combustion engines. Although currently HHO gas only used as a fuel extender, but in the future with continuing research, HHO gas is expected to main energy source for Otto and Diesel engines. Results of combustion from $\mathrm{HHO}$ gas extender in gasoline or diesel fuel can improve engine performance and reduce pollution levels $[4,5,6]$.

HHO gas generator system direct connection can cause the temperature rise in the generator until it reaches $90{ }^{\circ} \mathrm{C}$. This can cause the tube material $\mathrm{HHO}$ gas generators can not stand and will undergo melting. If the temperature continues to rise, it will also reduce the quality of $\mathrm{HHO}$ gas because the gas produced will be mixed with water vapor. Research on the optimization of $\mathrm{HHO}$ gas generators continue to be developed to get the best $\mathrm{HHO}$ gas production at temperatures below $70{ }^{\circ} \mathrm{C}$ [7].

Research on the HHO gas continues to be developed, especially to produce optimum of $\mathrm{HHO}$ gas quality. Many variations have been done, which consists of variations of electrode type, coil and composition, type of catalyst used, and type of water. But all of them still have not been able to produce HHO gas quality as expected. The next development is to control the input electrical current from the power source to the HHO gas generator. Pulse width modulation, pwm is an electronic circuit that is able to regulate current input into $\mathrm{HHO}$ gas generator, which can be set is duty cycle and frequency of current input [8]. Through the setting duty cycle and frequency current into HHO gas generator is expected to lower the temperature of the $\mathrm{HHO}$ gas generator which rose drastically on without pwm generator, so that no water vapor from the resulting $\mathrm{HHO}$ gas generators and the construction of the generator can be more durable. Pwm adjustable parameters to be varied to produce a pure $\mathrm{HHO}$ gas generator at a temperature below $60^{\circ} \mathrm{C}$.

HHO gas generator application in an internal combustion engine that has been done by several researchers $[9,10,11]$. 
Novriyandi[9] apply HHO gas generator on a $150 \mathrm{cc}$ motorcycle. The results showed there has been increased performance such as power, torque, mean effective pressure, thermal efficiency, respectively increased by $12.96 \%$, $13.59 \%, 15.09 \%$ and $20.83 \%$ and sfc decreased by $22,22 \%$. Musmar and Rousan research results[10] showed that the addition of HHO gas generator with wet type of engine can reduce specific fuel consumption, the content of nitrogen oxide emissions and carbon monoxide, respectively $30 \%$, $50 \%$ and $20 \%$. Aminuddin [11] using CNG gas fuel for engines Sinjai and the results showed a decrease in the content of $\mathrm{CO}$ and $\mathrm{HC}$ emissions respectively $30.91 \%$ and $19.9 \%$.

Based on these descriptions, this paper explains the application of HHO gas generator dry cell type with pulse width modulation on Sinjai spark ignition engine performance.

\section{LITERATURE REVIEW}

\subsection{Review of HHO Gas}

Water $\left(\mathrm{H}_{2} \mathrm{O}\right)$ is a compound that is most important in life, which consists of a compound of hydrogen $\left(\mathrm{H}_{2}\right)$ and oxygen $\left(\mathrm{O}_{2}\right)$. While gas $\mathrm{HHO}$ gas is a result of the decomposition of pure water $\left(\mathrm{H}_{2} \mathrm{O}\right)$ through electrolysis process [3], as shown in Figure 1.

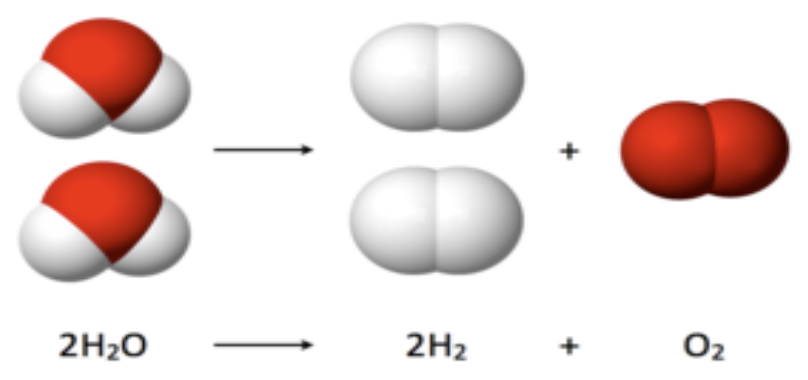

Figure 1. Decomposition of water molecules into HHO Gas

The electrolysis of water is basically done by passing an electric current through the water to the two electrodes (cathode and anode) as show in Fig 2. In order for the electrolysis process can happen quickly, the water is mixed with a liquid electrolyte as a catalyst. Electrode is useful as a conductor of electric current from the power supply voltage source to the water to be electrolyzed. At electrolysis using DC current, the electrodes are divided into two poles: positive as the anode and negative as the cathode. Electrode material influence on $\mathrm{HHO}$ gas production from water electrolysis process so that the electrode material must be selected from a material which has electrical conductivity and good corrosion resistance. Electrodes used in this research using $316 \mathrm{~L}$ type of stainless steel plate.

By dissolving the amount of electrolytes in the water will increase the value of the electrical conductivity of water. Thus, the rate of the reaction to decompose water molecules $\left(\mathrm{H}_{2} \mathrm{O}\right)$ into $\mathrm{H}_{2}$ and $\mathrm{O}_{2}$ becomes faster and also can reduce the energy needed for electrolysis process [2]. If the electrolyte in an amount more dissolved into the water, the electrical conductivity of the water will be higher, causing the value of HHO gas production rate will also increase. However, if the electrolyte is too much dissolved into the water, the energy required to produce $\mathrm{HHO}$ gas will also increase due to the electrolyte solution is saturated causing movement of ions in the electrolyte to be blocked. In this study, the electrolyte used is potassium hydroxide (KOH) [9].

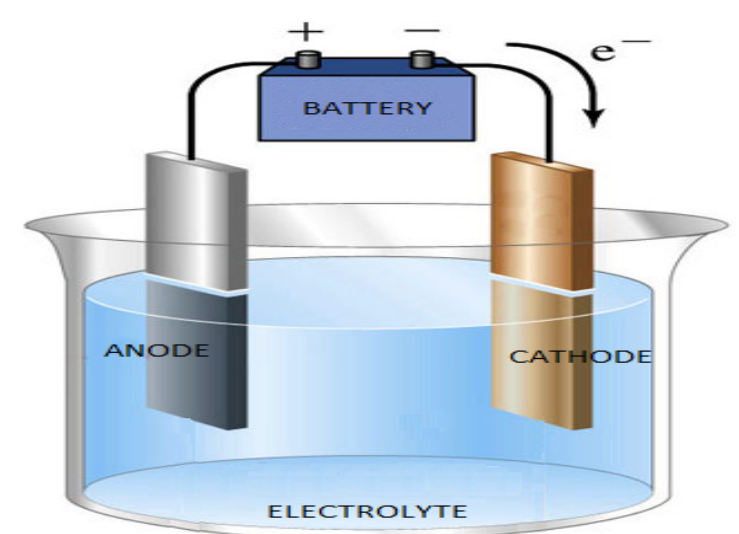

Figure 2. Schematic hydrolysis process of water

Acid equilibrium reaction:

Cathode (Reduction)

$2 \mathrm{H}^{+}(\mathrm{aq})+2 \mathrm{q}^{-} \rightarrow \mathrm{H}_{2(\mathrm{~g})}$

Anode (Oxidation)

$2 \mathrm{H}_{2} \mathrm{O}_{(\mathrm{D}} \rightarrow \mathrm{O}_{2(\mathrm{~g})}+4 \mathrm{H}^{+}(\mathrm{aq})+4 \mathrm{f}^{-}$

Base equilibrium reaction:

Cathode (Reduction)

$2 \mathrm{H}_{2} \mathrm{O}_{\mathrm{CD}}+2 \theta^{-} \rightarrow \mathrm{H}_{2 \mathrm{~g})}+2 \mathrm{OH}^{-} \mathrm{aq}$

Anode (Oxidation)

$\left.4 \mathrm{OH}^{-} \mathrm{Gaq}\right) \mathrm{O}_{2 \mathrm{~g}}+2 \mathrm{H}_{2} \mathrm{O}_{\mathrm{DO}}+4 e^{-}$

Overall reaction:

$2 \mathrm{H}_{2} \mathrm{O}_{(\mathrm{l})} \rightarrow 2 \mathrm{H}_{2(\mathrm{~g})}+\mathrm{O}_{2(\mathrm{~g})}$

If the electrolyte used is an alkaline solution such as $\mathrm{KOH}$, base reaction will occur. On this base reaction, a reduction reaction occurs on the cathode where water molecules bind electrons (e-) and then be broken into hydrogen gas $\left(\mathrm{H}_{2}\right)$ and anion $\mathrm{OH}-$. The $\mathrm{OH}$ - anions are attracted to the anode side and will be broken into oxygen gas and $\mathrm{H}_{2} \mathrm{O}$ molecular (1). Hydrogen gas has several characteristics are: colorless, flammable, very light and very easy to react with other chemicals. However HHO gas under normal conditions does not burn by itself without ignited by the fire.

\subsection{HHO Gas Generator Type}

HHO gas generator is composed of two basic components, tube generator and a power source. Tube generator consists of a tube, a pair of electrodes and electrolyte, while the power source such as a battery. This generator works on the principle of water electrolysis. HHO gas generators are classified into two types as follows: 


\section{A. Dry Cell Type}

HHO gas generator is where partially of the electrode is not submerged in electrolyte and electrolytes only fill the gaps between the electrodes themselves as show in Fig 3 . Advantages types of dry cell $\mathrm{HHO}$ gas generator is the first Electrolyzed water less, ie the only water trapped between the cell plates. Heat generated is relatively small, due to the circulation between the hot and cold water in the reservoir. The electric current used is relatively smaller, because the power is converted into heat less.
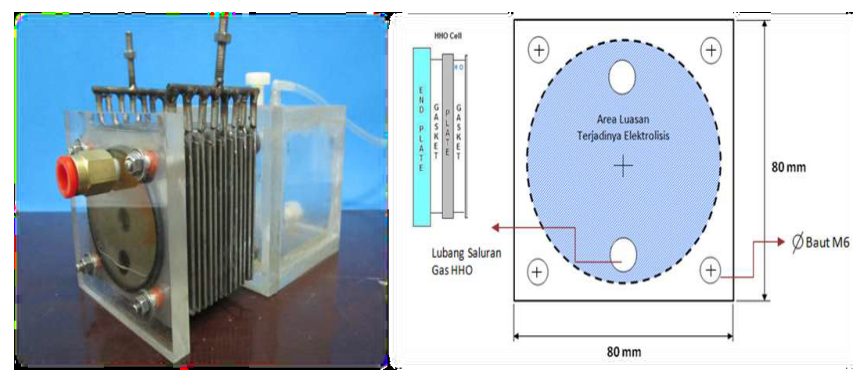

Figure 3. HHO gas Generator dry Cell type a.Generator construction $b$.Electrodes area

Area of a circle on the plate electrodes immersed in water is the area occurrence of electrolysis to produce HHO gas, while the other area is not submerged in water and in dry conditions. The area of occurrence of electrolysis process approximately $60 \%$ of the total plate area and should be limited to the o-ring or seal with a diameter of $80 \mathrm{~mm}$ on each plate were used. Moreover on each plate there are two holes with a diameter of $12 \mathrm{~mm}$ for $\mathrm{HHO}$ gas line located at the top and at the bottom.

\section{B. Wet Cell Type}

A HHO gas generator in which all the electrodes immersed in the electrolyte liquid in a vessel of water as show in Fig 4. Advantages of the HHO gas generators wet cell type are first, gas production generally more quantity and stable, second, generator maintenance easier and third $\mathrm{HHO}$ generator design manufacture easier.

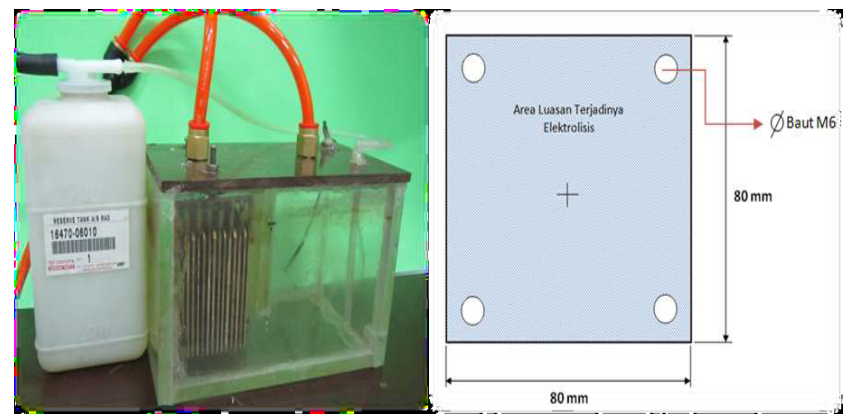

Figure 4. Generator gas HHO Wet Cell type a.Generator construction b.Electrodes area

In the wet cell type, all areas of the electrode plate area submerged in water to the electrolysis process produces HHO gas. So that magnitude of electrolysis area same with an area of each plate used are dimensions of $80 \mathrm{~mm} \times 80$ $\mathrm{mm}$.

\subsection{Hho Gas Generator Performance}

The performance parameters of the HHO gas generators are as follows:

\section{A. Generator Power Input}

To produce HHO gas using the process of electrolysis of water is needed electric energy. Therefore, it should be known a magnitude of generator input power. Formulation to find the input power is: $\mathrm{P}=\mathrm{V} \times \mathrm{I}$ where: $\mathrm{P}=$ Power input of $\mathrm{HHO}$ gas generator (watts) $\mathrm{V}=$ voltage (volts) and $\mathrm{I}=$ electrical current (Ampere).

\section{B. Hho Gas Production}

The amount of production of HHO gas produced by the $\mathrm{HHO}$ gas generator is measured using gas flow mater.

\section{Specific Energy Input}

Specific energy input is defined as the amount of energy required to process the electrolysis of water in kjoule to produce $1 \mathrm{~kg}$ of $\mathrm{HHO}$ gas.

\section{Generator Efficiency}

Generator efficiency is the ratio of useful energy to the energy supplied on system. At the HHO generator, useful energy is the product of the electrolysis of water in the form of $\mathrm{HHO}$ gas which is obtained in the reaction of decomposition of water $(\mathrm{H} 2 \mathrm{O}): 2 \mathrm{H} 2 \mathrm{O}(\mathrm{l}) \rightarrow 2 \mathrm{H} 2(\mathrm{~g})+\mathrm{O} 2$ (g) - 285.84. This reaction is an endothermic reaction that requires energy enthalpy of $285.85 \mathrm{~kJ} / \mathrm{mol}$. The amount of HHO gas mole obtained from the ideal gas equation on STP conditions [4]. While the amount of energy supplied calculated based on the input voltage and current to the electrolysis process.

\section{Generator Hho Temperatur}

The process of electrolysis of water into $\mathrm{HHO}$ gas on $\mathrm{HHO}$ Gas Generator influenced by the input electric current to the electrodes and the fluid in the generator. As time goes on generator continues to work to produce $\mathrm{HHO}$ gas, electric current flows through a conductor is the greater, causing fluid temperature rise in the HHO generator. This is caused by the amount of electric current from the input power source is not controlled, so most current and voltage is not used for the electrolysis process, but only generates heat continues to rise. So that needs to be considered to keep the quality of $\mathrm{HHO}$ gas by controlling the fluid temperature below $60{ }^{\circ} \mathrm{C}$ so as not to produce water vapor.

\subsection{Pulse Width Modulation System}

Pwm is an electronic circuit to control the amount of electric current that enter equipment and to avoid excessive power dissipation in the battery and the generator HHO. Pwm is one of methods to control current and voltage by regulating the percentage of pulse width to the period of a square signal in the form of a periodic voltage applied to the motor as a power source. Pwm signal can be constructed using analog 
methods using op-amp circuit or by using a digital method that could be affected by the resolution of the pwm itself. Pwm electronic circuits can be made using a 555 timer IC or IC LM324N. Timer IC is one type of timer that has the ability pwm controller with pulse width control features 0 to $100 \%$. Pulse voltage of a DC power source that is used can be regulated its duty cycle. Duty cycle is then used as a pwm signal [5].

Mosfet drivers are needed on the use of pwm. It serves as a power component that requires little input current and voltage controlled. Mosfet has a driver circuit to set the switching mosfet through the gate. Ignition mosfet to be able to deliver the required voltage $\mathrm{V}_{\mathrm{GS}}$ greater than or equal to the threshold voltage (minimum voltage required to deliver mosfet) of the mosfet.

Duty cycle is the ratio of the length of time a signal in a state of high with the length of time a signal in a state (high + low) as shown in Fig 5. Duty cycle is very useful in designing tools that uses the concept of pwm. By regulating the pulse width "ON" and "OFF" in one period of the wave through the provision of reference signal output from a pwm then it will get the desired duty cycle.

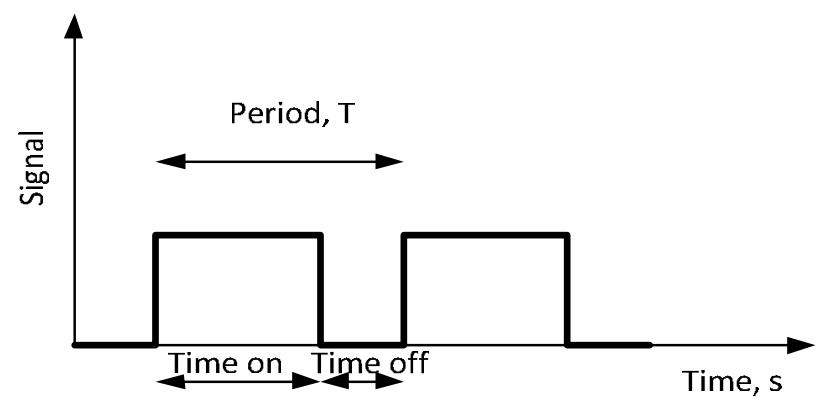

Figure 5. Duty cycle of pwm system

\section{EXPERIMENTAL METHODS}

\subsection{Experimental Setup}

Assembly of the HHO generator is shown in Figure 6 as follows:

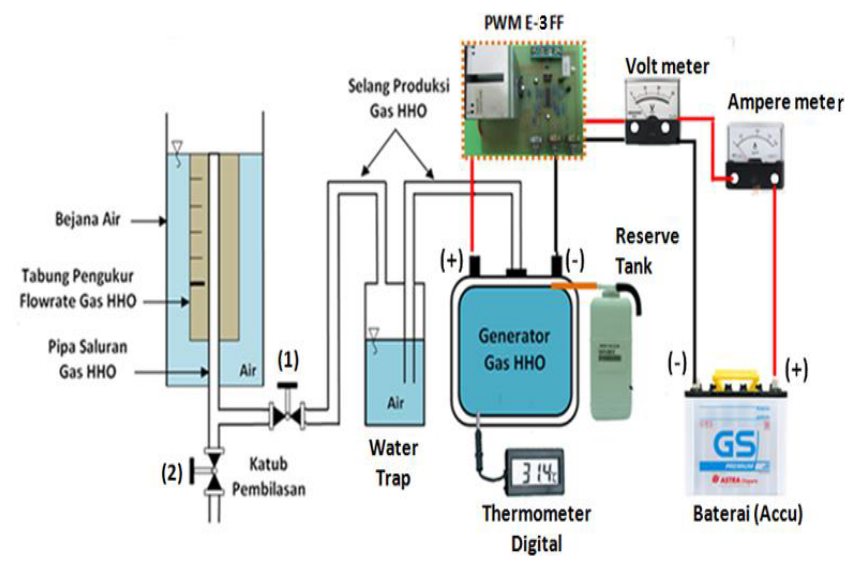

Fig 6. Assembly of HHO gas generator
In this study, the spark ignition gasoline engine used is Sinjai engine $20 \mathrm{~kW}$, four stroke two cylinder [12]. The engine specifications are given in Table 1 as below.

Table 1. SINJAI engine specifications

\begin{tabular}{|l|l|}
\hline Engine type & SINJ AI 20 \\
\hline Number of cylinder & 2 \\
\hline Bore $x$ stroke & $76 \times 71 \mathrm{~mm}$ \\
\hline Displacement volume & $650 \mathrm{cc}$ \\
\hline Compression ratio & 9 \\
\hline Control system & Programmable ECU \\
\hline Fuel intake system & Multi port injection \\
\hline Maximum torque & $57 \mathrm{Nm} / 3000 \mathrm{rpm}$ \\
\hline Maximum power & $20 \mathrm{~kW} / 4500 \mathrm{rpm}$ \\
\hline Coolant system & Liquid with radiator \\
\hline \hline
\end{tabular}

In the experimental, the engine is modified into dual fuel system gasoline-HHO gas engine. HHO gas fed into the engine through the addition of shaped venturi mixer equipment and assembly on the air intake manifold after the air filter. Waterbrake dynamometer with power capacity 120 hp used in these experiments. The fuel consumption was measured by the time fuel consumption per $25 \mathrm{cc}$ of fuel in a measuring glass, whereas combustion air consumption was measured using an air flow meter. The fuel measuring glass was fitted to Sinjai engine and it contained gasoline fuel. A schematic diagram of experimental setup is shown in Fig. 7.

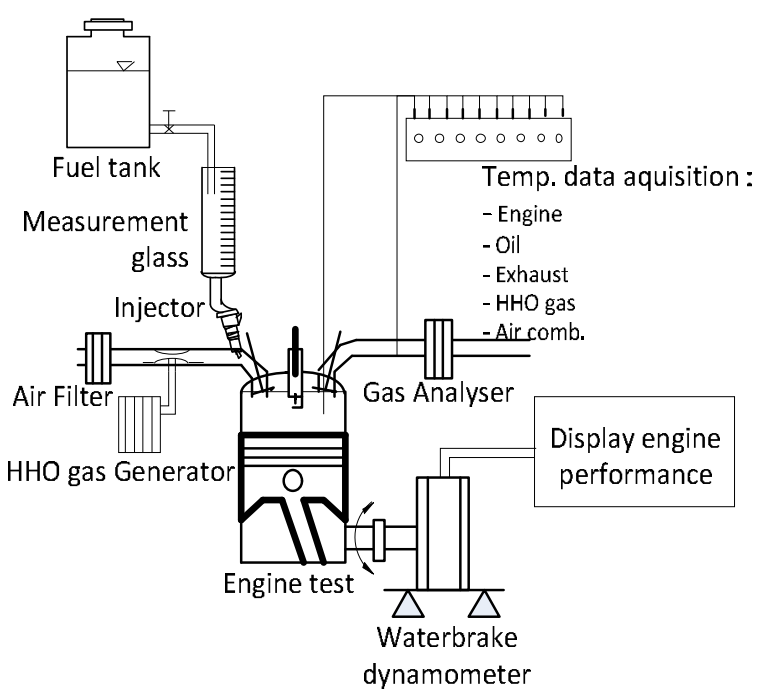

Fig. 7. Schematic diagram of the experimental setup

This engine is equipped with a programmable electronic control unit which has the facility to adjust the suitability of injection and ignition timings. ECU function is to control the quantity of fuel, injection timing, ignition timing and engine speed by receiving signals from six sensors [12]. These sensors are oxygen sensor, manifold air pressure sensor, intake air temperature sensor, throttle position sensor, cooled water temperature sensor and engine speed sensor. A multi port fuel injection system with is used to inject the gasoline fuel into intake valve area of the port to the combustion chamber. 
ECU engine was employed to optimize air fuel ratio, equivalence ratio and ignition timing for all engine configurations and fuel types. For all conditions fuel/air mixture equivalence ratio was set to $1 \sim 1,1$, to minimize the fuel amount necessary to obtain the maximum torque. The ignition timing was set for minimum advance for best torque (MBT) or limited by knock whichever occurred first[13].

A series of experiments were carried out using gasoline, and continued with adding generator HHO gas. All fuels were tested with variable engine speed method. The engine was started using gasoline fuel and it was operated until it reached the steady state condition. The engine speed, fuel consumption, waterbrake load engine, emission parameters such as $\mathrm{CO}, \mathrm{HC}, \mathrm{CO}_{2}, \mathrm{O}_{2}$ and exhaust temperature were measured, while the brake power, brake specific fuel consumption, brake mean effective pressure and brake thermal efficiency were computed. All experiments have been carried out at full open throttle setting.

Table 2. Fuel properties at $300 \mathrm{~K}$ and $1 \mathrm{~atm}$

\begin{tabular}{|c|l|c|c|c|}
\hline \multirow{2}{*}{ No } & \multicolumn{2}{|c|}{ Properties } & \multirow{2}{*}{ Unit } & \multicolumn{2}{|c|}{ Fuel } \\
\cline { 4 - 5 } & & & Gasoline & Hidrogen \\
\hline 1 & Chemical Formula & - & C8H18 & H2 \\
\hline 2 & Research Octane Number, RON & - & 88 & $>130$ \\
\hline 3 & Density at 15 $15^{\circ} \mathrm{C}$ & $\mathrm{kg} / \mathrm{m} 3$ & 760 & 0,0898 \\
\hline 4 & Minimum ignition energy & $\mathrm{m} J$ & 0,28 & 0,02 \\
\hline 5 & Lower Heating Value & $\mathrm{MJ} / \mathrm{kg}$ & 42,69 & 120 \\
\hline 6 & Laminer Flame Speed & $\mathrm{cm} / \mathrm{s}$ & 43 & 290 \\
\hline 7 & Molar Weight & $\mathrm{kg} / \mathrm{kmol}$ & 102,5 & 2,016 \\
\hline 8 & Stoichiometric Air fuel Ratio & $\mathrm{kg} / \mathrm{kg}$ & 14,7 & 34,2 \\
\hline 9 & Flammabilitylimits $(\lambda)$ & - & $0,26-1,51$ & $0,14-10$ \\
\hline 10 & Adiabaticflame temperature & $\mathrm{K}$ & 2276 & 2390 \\
\hline 11 & Kinematic viscosity & $\mathrm{mm} 2 / \mathrm{s}$ & 15,2 & 21,6 \\
\hline 12 & Autoignition temperature & $\mathrm{K}$ & 690 & 858 \\
\hline
\end{tabular}

\section{RESULTS AND DISCUSSIONS}

Based on the results of performance testing of HHO gas generator, obtained the best performance of the $\mathrm{HHO}$ gas generator is on a duty cycle of $40 \%$, ie with a specific energy input amounted to $33.121 \mathrm{MJ} / \mathrm{kg}$, generator efficiency of $20.064 \%$ and generator temperature can be maintained below $60{ }^{\circ} \mathrm{C}$. More results shown in Figure 8 .

HHO gas composed of hydrogen and oxygen atoms. Based on the properties of fuel as shown in Table 2 indicate that the hydrogen atom is small and has a very low density compared to gasoline. Hydrogen also has an octane number above 130 indicates a tendency to be more resistant to the occurrence of knocking. In addition, the stoichiometric conditions, the hydrogen-air mixture has a laminar burning speed and adiabatic flame temperature higher than gasoline, thus potentially resulting in emissions of nitrogen oxides (NOx) higher.

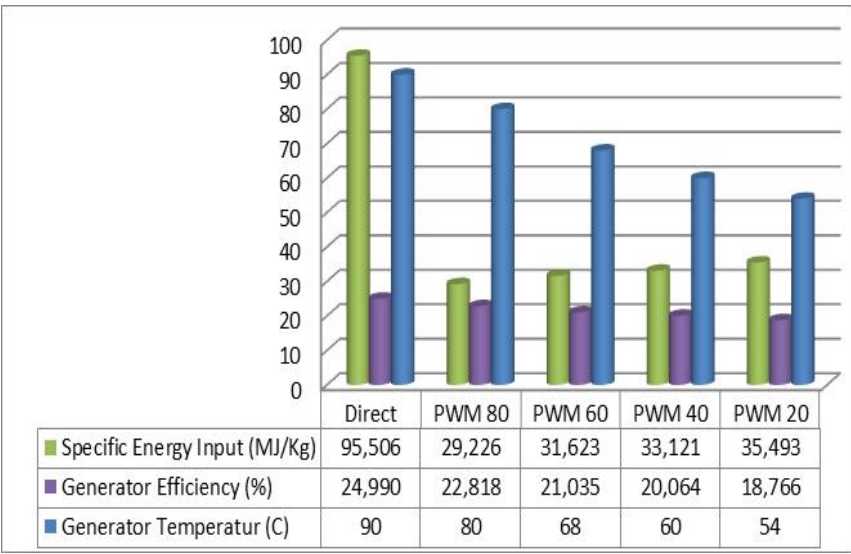

Fig.8. Performance of $\mathrm{HHO}$ gas generator

With a higher calorific value and low density, hydrogen can be used as a fuel in internal combustion engines. Based on the performance parameters of the engine, operating with hydrogen could reduce the bsfc. However, due to the loss of volumetric efficiency, mainly due to high inlet temperatures, the engine tends to produce lower power until $20 \%$ compared to gasoline [14]. The minimum ignition energy of a hydrogen-air mixture at atmospheric conditions is lower than for gasoline-air mixtures. It is normally measured using a capacitive spark discharge, and this value is dependent on the spark gap. It is only $0.02 \mathrm{~mJ}$, which is obtained for hydrogen concentrations of $22-26 \%$ ( $\square=1.2-$ 1.5) [1]. The wide range of flammability limits, with flammable mixtures from as lean as $\square=10$ to as rich as $\square \square \square 0.14$ allows a wide range of engine power output through changes in the mixture equivalence ratio. The flammability limits widen with increasing temperature and lower flammability limit increases with pressure, with the upper flammability limit having complex behavior [1].

Furthermore $\mathrm{HHO}$ gas generator is applied on the internal combustion engine. The engine performance tests were carried out to study the application of $\mathrm{HHO}$ gas generator type dry cell with pulse width modulation on spark ignition Sinjai engine performance. The tests were conducted with add HHO gas generator at intake manifold and varied of ignition timing retarded between $12-15^{\circ}$ btdc. Full open trottle test method was conducted variable engine speed test runs from $2000 \mathrm{rpm}$ to $5000 \mathrm{rpm}$, in $500 \mathrm{rpm}$ engine speed intervals with adjusting of the brake water loading switches.

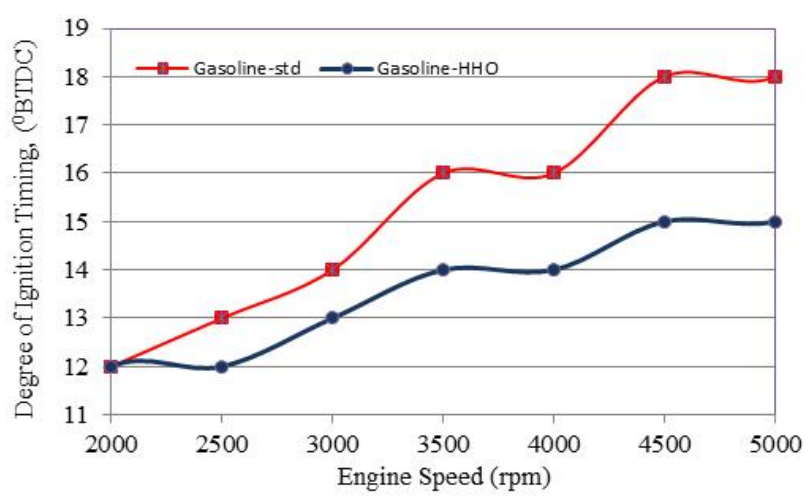

Fig.9. Mapping degree of ignition timing at MBT condition 
Engine performance testing conducted in a variable speed with full open throttle test method. To optimize the performance of the engine, we do the settings degrees of ignition timing. The ignition timing was set for minimum advanced of spark ignition for best torque, MBT [13]. Mapping degree of ignition timing at MBT condition was showed by Fig 9. The trends observed in Fig. 2 are explained that for all variable testing indicate that the degree of ignition timing is advanced due to the increase in speed engine. For gasoline fuel the degree of ignition timing gradually rises, ranging from $12^{\circ} \mathrm{BTDC}$ at engine speed $2000 \mathrm{rpm}$ up to $18^{0} \mathrm{BTDC}$ at engine speed $5000 \mathrm{rpm}$. While addition HHO gas has the same tendency that the degree of the ignition timing is more advanced due to higher engine speed but the value of degree of ignition timing retarded, from $12{ }^{0} \mathrm{BTDC}$ at engine speed $2000 \mathrm{rpm}$ up to $15^{\circ} \mathrm{BTDC}$ at engine speed $5000 \mathrm{rpm}$.

Fig. 10. shows the influence of addition HHO gas to engine performance at standard and MBT ignition timing conditions. Torque is a measure of the ability to produce a working engine and is used to overcome the obstacles in the way or to raise engine speed. Fig. 10 showed a tendency that the torque starts to rise from the lower engine speed (2000 rpm) to achieve maximum torque at a certain engine speed $(3000 \sim 3500 \mathrm{rpm})$ and further decreased at higher engine speed (5000 rpm).

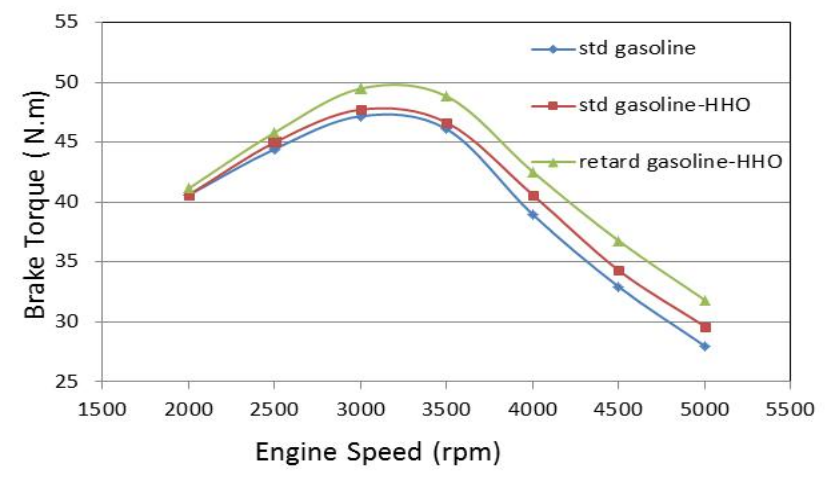

Fig.10. Brake torque at variation fuel and engine speed

According Sudarmanta et al [13], a tendency of increase in torque with increasing engine speed until the round of 3000 $\sim 3500 \mathrm{rpm}$ and subsequently tends to decrease with increasing engine speed, caused by turbulent flow into the combustion chamber which is higher as the increase in engine speed so as to enhance the mixing of air with fuel and fire propagation. While the tendency to decrease the torque on the engine speed above $3500 \mathrm{rpm}$ due to increased friction losses, heat losses and incomplete combustion process. The influence of the addition of $\mathrm{HHO}$ gas in gasoline to torque, displays the tendency of increasing engine speed, torque rise will also increase. The addition of HHO gas on engine with standard ignition timing can generate torque rise to an average of $2.27 \%$, while on engine with retarded ignition timing timing is adjusted to MBT as graph in Figure 9 shows the increase in engine torque by an average of $6.55 \%$. This is because HHO gas contribute to the process of mixing, atomization and heat release
The magnitude of engine power is proportional to the torque that occurs, because it is related to the braking loads on the water brake dynamometer. The greater the braking loads on a dynamometer showed that the torque that occurs will also increase. Figure 11 shows the effect of addition of HHO gas to the engine power and the results showed the same trends as the torque graph in Figure 10, the addition of HHO gas effectively gives rise to power in the middle and upper engine speed. The influence of the addition of HHO gas on engine with the standard ignition timing indicates an increase in the average engine power reached $2.76 \%$, while on engine with the retarded ignition timing is adjusted to MBT as graph in Figure 9 shows the increase in engine power by an average of $7.65 \%$.

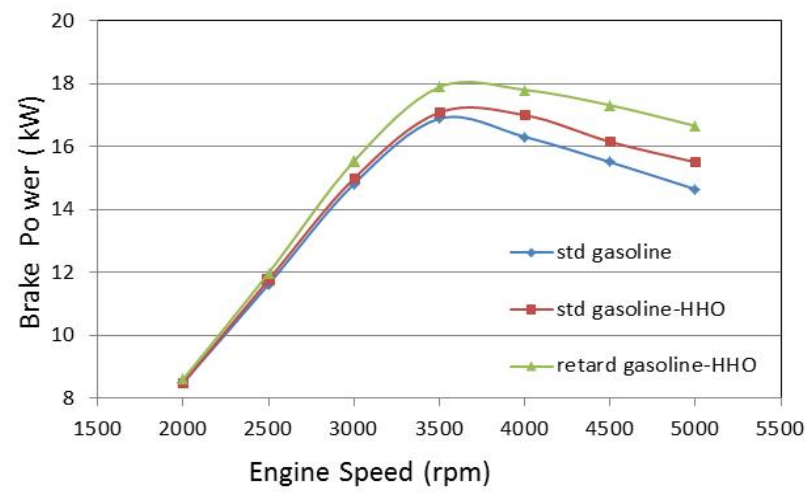

Fig.11.Brake power at variation fuel and engine speed

Furthermore, the parameters used to describe performance of engine with reciprocating piston type is brake mean effectif pressure, bmep. Bmep is a theoretical constant pressure which, if acting on the piston during the power stroke, will produce the same net work really developed in one cycle. Fig. 12 shows the influence of the addition of HHO gas to bmep.

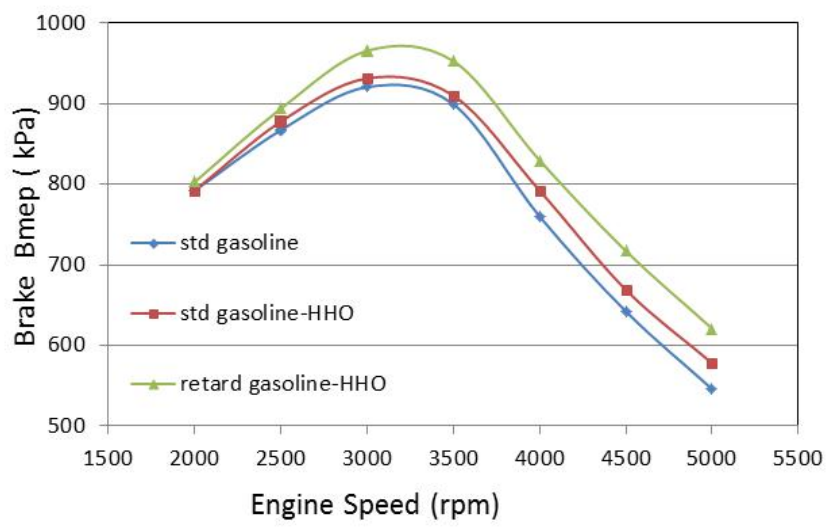

Fig.12. Bmep at variation fuel and engine speed

Same as the trend for the torque and power, the magnitude of bmep is proportional to the torque that occurs, because it is related to the braking loads on the water brake dynamometer. The greater the braking loads on a dynamometer showed that the torque that occurs will also increase. Figure 12 shows the effect of addition of HHO gas 
to bmep and the results showed the same trends as the torque graph in Figure 10, the addition of HHO gas effectively gives rise to power in the middle and upper engine speed. The influence of the addition of HHO gas on engine with the standard ignition timing indicates an average increase in bmep until $2.27 \%$, while on engine with the retarded ignition timing is adjusted to MBT as graph in Figure 9 shows an average increase in bmep until $6,55 \%$.

As shown in Fig. previously, by setting the ignition timing to follow MBT as graph in Figure 9 produces higher torque, power and BMEP, respectively. Increased these parameters with retarded ignition timing were caused by the presence of HHO gas assist mixing process becomes more evenly distributed, atomization becomes more active as well as combustion and flame propagation becomes more quickly and thoroughly. Besides the presence of oxygen in the HHO gas is also effectively assists the mixing process, oxidation and combustion, respectively [12].

The brake specific fuel consumption, bsfc illustrates the flow rate of fuel required by the engine per unit of power generated. Due to the heating values, LHV from hidrogen gas is higher than gasoline (as show in Table 2), the amount of mass that is required for the combustion process unity generated power becomes less than that of gasoline. The explains why bsfc HHO gas is higher than gasoline, as shown in Fig. 13.

From Figure 13 shows that the addition of HHO gas can reduce the magnitude of bsfc compared to gasoline fuel. The influence of the addition of HHO gas on engine with the standard ignition timing indicates an decrease in the average bsfc until $7.76 \%$, while on engine with the retarded ignition timing is adjusted to MBT as graph in Figure 9 shows the decrease until $22,06 \%$.

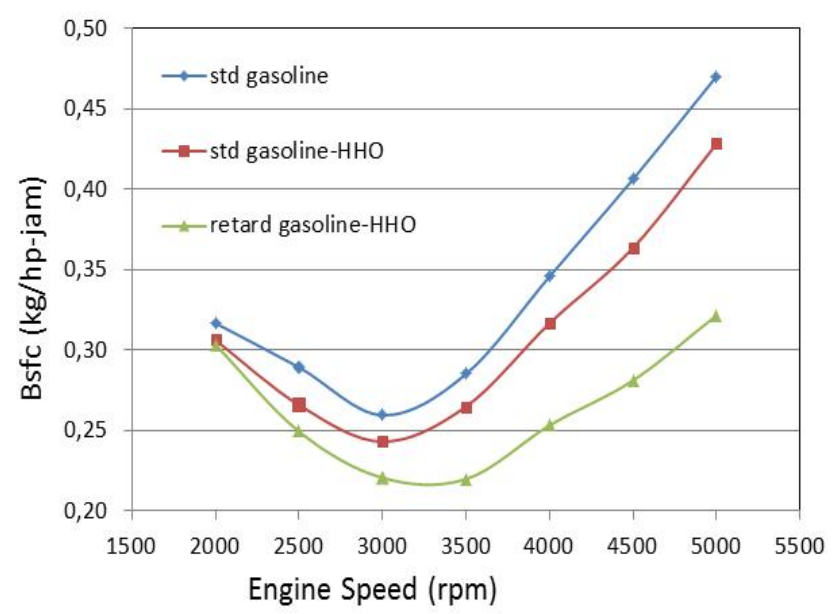

Fig.13. Bsfc at variation fuel and engine speed

The thermal efficiency is a parameter that indicates the magnitude of conversion of stored energy in the fuel into the engine power produced. In generally, it is defined as the ratio of useful energy produced by the engine with the energy stored in fuel.

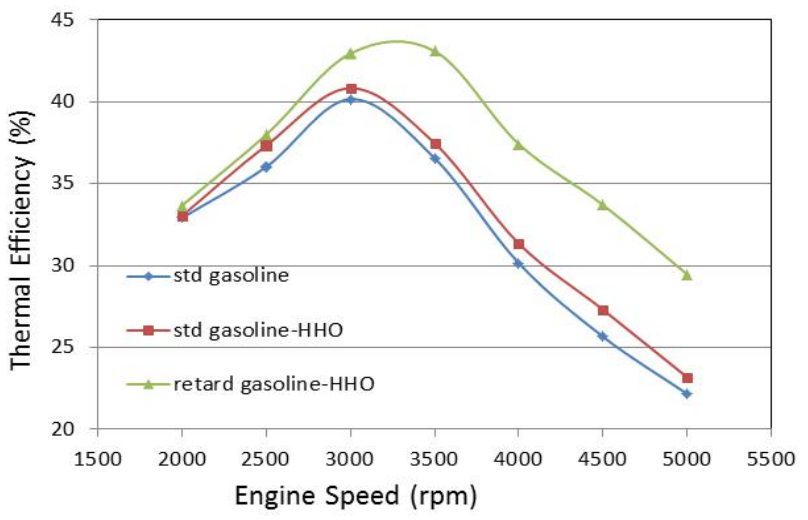

Fig.14 Thermal efficiency at variation fuel and engine speed

Thermal efficiency is influenced on the quality of the air and fuel mixture is burned in the combustion chamber. As shown on Fig. 14, the addition of HHO gas can increase the magnitude of thermal efficiency compared to gasoline fuel. The influence of the addition of HHO gas on engine with the standard ignition timing indicates an increase in the average thermal efficiency until $3,08 \%$, while on engine with the retarded ignition timing is adjusted to MBT as graph in Figure 9 shows the increase until 15,50\%.

These results indicate that the addition of HHO gas provides a dual function, ie beside of hydrogen gas has a higher calorific value, also the presence of oxygen gas is able to activate the process of mixing, atomization and oxidation that occurs, respectively that the heat release process can occur more optimally.

\section{CONCLUSIONS}

Optimum performance of HHO gas generator is generated by pwm with $40 \%$ duty cycle with parameters such as specific energy input of $33121 \mathrm{MJ} / \mathrm{kg}$, generator efficiency of $20,064 \%$ and generator temperature can be maintained below $60{ }^{0} \mathrm{C}$.

Application of $\mathrm{HHO}$ gas generator in point above on standart ignition timing Sinjai engine produce in an increase of performance such as torque, power, BMEP and thermal efficiency respectively of $2.27 \%, 2.76 \%$ and $3.05 \%$ and a decrease of bsfc $7.76 \%$.

Retarded ignition timing is adjusted to MBT is able to increase performance such as torque, power, thermal efficiency, respectively $6.55 \%, 7,65 \%, 15,50 \%$ and a decrease of bsfc $22,06 \%$.

\section{ACKNOWLEDGEMENT}

This research was part of research activities funded by the ministry of research and technology-higher education with laboratory research schema through the Institute's research and community service (LPPM ) ITS for fiscal year 2015. In this opportunity, authors would like to thank Kementerian Ristek-Dikti RI and LPPM ITS thanks to funding that has been given. Authors also thank to the HHO gas generator team. 


\section{REFERENCES}

[1]. Verhelst, S. and Wallner, T., Hydrogen-fueled internal combustion engines, Progress in Energy and Combustion Science 35 (2009) 490-527.

[2]. Zoulias, E., Varkaraki, E. Lymberopoulos, N., Christodoulou, C.N., and Karagiorgis, N., A review on water electrolysis, Centre for Renewable Energy Sources (CRES), Pikermi, Greece and Frederick Research Center (FRC), Nicosia, Cyprus 2003.

[3]. Cheng, T.S. 1992. Chemistry Book 3. Second Edition. EPB Publisher Pte. Singapura.

[4]. Al-Rousan, A.A., Reduction of fuel consumption in gasoline engines by introducing $\mathrm{HHO}$ gas into intake manifold, international journal of hydrogen energy 35 (2010) 12930-12935.

[5]. Changwei Ji and Wang, S., Combustion and emissions performance of a hybrid hydrogen-gasoline engine at idle and lean conditions, international journal of hydrogen energy 35 (2010) 346-355

[6]. Rizal, S. and Sungkono, D., The 6 cell HHO Gas Generator Dry Cell Type the Composed Series and Its Implementation At Nissan Diesel Dump Truck CWA 211 NHRR-S $6925 \mathrm{cc}$, POMITS ENGINEERING JOURNAL Vol. 1, No. 2, (2014) ISSN: 2301-9271 (in Indonesia).

[7]. Bhardwaj, S., Verma, A.S., and Sharma, S.K., Effect of Brown gas on the performance of a four stroke gasoline engine, International Journal of Emerging Technology and Advanced Engineering (Online), Volume 4, Special Issue 1, February 2014.

[8]. Ghiffari, Y.A. and Sungkono, D., Study of HHO Gas Generator Characteristics Wet Dry Cell and Cell Type with dimension of $80 \times 80 \mathrm{~mm}$ with the addition of PWM E-3 FF (1 kHz), POMITS ENGINEERING JOURNAL Vol. 1, No. 1, (2013) (in Indonesia).

[9]. Nofriyandi. R , (2014), Gas HHO application on a 150cc motorcycle, S2 Thesis, Department of Mechanical Engineering, Graduate program ITS, Surabaya (in Indonesia).

[10]. Musmar, S.A., and Al-Rousan, A.A., Effect of HHO gas on combustion emissions in gasoline engines, Fuel 90 (2011) 3066-3070.

[11]. Aminudin, A. And Sudarmanta, B., The performance improved of Sinjai engine bi-fuel system (gasolinecompressed natural gas) with adjusted of injection duration and air fuel ratio, Proceedings of the Graduate National CONFERENCE XIV - ITS, 2014 (in Indonesia).

[12]. Sudarmanta B., Darsopuspito, S. \& Sungkono, D. "Influence of Bioethanol-gasoline blended fuel on performance and emissions characteristics from port injection Sinjai Engine $650 \mathrm{cc}$, Journal of Applied Mechanics and Materials Vol. 493, pp 273-280, 2014.

[13]. Sudarmanta B., Junipitoyo, B., Bachtiar, A. \& Sutantra, I.N., "Influence of the compression ratio and ignition timing on Sinjai Engine performance with $50 \%$ bioethanol-gasoline blended fuel", ARPN Journal of Engineering and Applied Sciences, Volume 11, No 4, (2016).

[14]. Yamin, J.A.A., Gupta, H.N., Bansal, B.B. \&
Srivastava, O.N., "Effect of combustion duration on the performance and emission characteristics of a spark ignition engine using hydrogen as a fuel", International Journal of Hydrogen Energy 25 (2000) 581-589.

\section{BIOGRAPHIES}

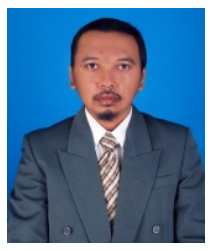

Bambang Sudarmanta is a lecturer in the department of mechanical engineering, Sepuluh Nopember Institute of technology, ITS Indonesia. Field of research are biofuels, combustion engineering and power plant.

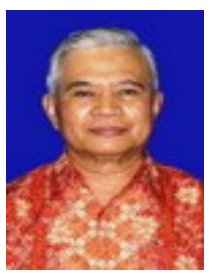

Sudjud Darsopuspito is a lecturer in the department of mechanical engineering, Sepuluh Nopember Institute of technology, ITS Indonesia. Field of research are termodynamics and heat transfer.

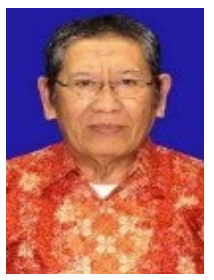

Djoko Sungkono is a emeritus professor in the department of mechanical engineering, Institute of Technology Indonesia. Field of research are internal combustion engine. 